\title{
Acute generalised skin rash secondary to the Nystatin Oral Suspension
}

\author{
Kamal Kant Sahu, ${ }^{\oplus}$ Ajay Kumar Mishra, Amos Lal, ${ }^{\oplus}$ Rahul Gandhi
}

Department of Internal

Medicine, Saint Vincent Hospital, Worcester, Massachusetts, USA

Correspondence to Dr Kamal Kant Sahu, drkksahu85@gmail.com

Accepted 6 May 2019

\section{DESCRIPTION}

A 65 -year-old male presented to emergency room (ER) for the complaint of skin rash of 2 days duration. Recently, patient was diagnosed with lung cancer for which he was receiving chemotherapy (cisplatin $60 \mathrm{mg} / \mathrm{m}^{2}$ on day 1 and etoposide injection $120 \mathrm{mg} / \mathrm{m}^{2}$ on days $1,2,3$ planned for total duration of 4 cycles). On the $10^{\text {th }}$ day following the $3^{\text {rd }}$ cycle, patient developed oral thrush for which he was prescribed topical antifungal, nystatin oral suspension for swish and rinse. However, the next day, he started developing skin rash predominantly involving upper chest, neck and back. The skin lesions were diffuse, ill-defined, multiple, erythematous maculopopular and non-pustular (figures 1 and 2). No evidence of haemodynamic instability, fever, neutropenia, respiratory distress was noted, thereby ruling out the common etiologies like anaphylactic shock, febrile neutropenia, viral exanthem and so on. Review of his medical records and medication list suggested no recent changes apart from addition of nystatin. Hence, a possible diagnosis of drug rash secondary to nystatin was considered and was replaced with oral fluconazole. Subsequently, no new skin rash was noted, and old lesions gradually faded over next 1 week. Nystatin induced drug rash was documented in patient's allergy list.

Skin eruptions have wide differentials, especially when patients are on chemotherapy. ${ }^{1}$ Any case with skin lesions should be thoroughly evaluated for paraneoplastic syndrome, viral exanthem, Sweet's syndrome, leukaemia cutis, allergies, drug reactions, thrombocytopenic purpura and so on. ${ }^{2}$ Nystatin is formulated in variety of forms: capsule (for intestinal candidiasis), cream/ointment/powder (for candida diaper dermatitis), oral suspension (for oropharyngeal candidiasis), vaginal tablets (for vulvovaginal candidiasis). Acute generalised exanthematous pustulosis, type IV hypersensitivity and contact dermatitis have rarely been reported in association with nystatin. ${ }^{3-6}$ Patch testing, histological

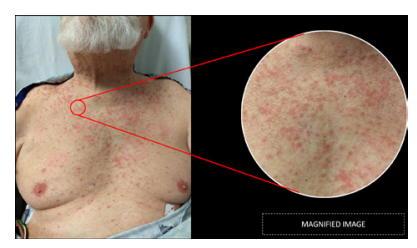

Figure 1 Image (front view) showing diffuse, illdefined, multiple, erythematous maculopapular rash over upper chest and neck, at few locations, lesions are coalescing to form patch as well.

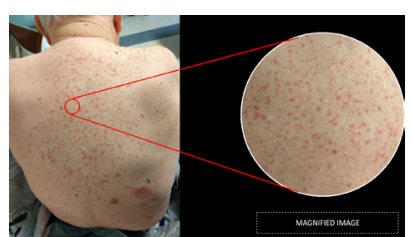

Figure 2 Back of the patient showing similar scattered maculopapular skin lesions.

examination and oral challenge test are often helpful in confirming the diagnosis. ${ }^{3-6}$ Our patient declined for both skin biopsy and patch testing; however, temporal correlation of developing skin lesions on initiating nystatin and dermatological recovery after discontinuing it confirmed the diagnosis. Many newer anticancer drugs have potential to cause dermatological adversities and hence an up-to-date knowledge is warranted while managing such patients. ${ }^{7-11}$

\section{Learning points}

- Contrary to general consensus, topical nystatin can have systemic allergic response.

- Any skin lesion should be thoroughly investigated for infection, infiltration, paraneoplastic syndrome and allergies.

- Review of electronic medical records and medication list can be of extreme importance to verify the offending drug.

Contributors KKS: manuscript writing. AKM: photography, management, editing. AL: literature research. RG: management, editing.

Funding The authors have not declared a specific grant for this research from any funding agency in the public, commercial or not-for-profit sectors.

Competing interests None declared.

Patient consent for publication Obtained.

Provenance and peer review Not commissioned; externally peer reviewed.

\section{REFERENCES}

1 Yanamandra U, Sahu KK, Malhotra P, et al. Photodermatosis secondary to hydroxyurea. BMJ Case Rep 2014;2014:bcr2014205974

2 Yanamandra U, Sahu KK, Khadwal A, et al. Recurrent sweet's syndrome in a case of AML. Indian J Hematol Blood Transfus 2016;32(Suppl 1):82-5.

3 Vega F, Ramos T, Las Heras P, et al. Concomitant sensitization to inhaled budesonide and oral nystatin presenting as allergic contact stomatitis and systemic allergic contact dermatitis. Cutis 2016;97:24-7 
Images in...

4 Martínez FV, Muñoz Pamplona MP, García EC, et al. Delayed hypersensitivity to oral nystatin. Contact Dermatitis 2007;57:200-1.

5 Barranco R, Tornero P, de Barrio M, et al. Type IV hypersensitivity to oral nystatin. Contact Dermatitis 2001:45:60.

6 Küchler A, Hamm H, Weidenthaler-Barth B, et al. Acute generalized exanthematous pustulosis following oral nystatin therapy: a report of three cases. Br J Dermatol 1997;137:808-11.

7 Sahu KK, Yanamandra U, Malhotra P. Ara-c related red ear syndrome. Ear Nose Throat J 2019;98:169-70.
8 Mishra AK, Sahu KK, James A. Disseminated herpes zoster following treatment with benralizumab. Clin Respir J 2019;13:189-91.

9 Sahu KK, Mishra A, Chastain I. Novel anticancers and dermatological adversities: old rivals but new challenges. BMJ Case Rep 2018;11:e227790.

10 Sahu KK, Sawatkar GU, Jeyaraman P, et al. Bullae And Blisters: A Rare Case of Bendamustine Skin Toxicity. Indian I Hematol Blood Transfus 2016:32(Suppl 1):368-9.

11 Sahu KK, Varma SC. Herpes zoster complicating bortezomib therapy. Indian J Med Res 2015;141:247-55

Copyright 2019 BMJ Publishing Group. All rights reserved. For permission to reuse any of this content visit

https://www.bmj.com/company/products-services/rights-and-licensing/permissions/

BMJ Case Report Fellows may re-use this article for personal use and teaching without any further permission.

Become a Fellow of BMJ Case Reports today and you can:

- Submit as many cases as you like

- Enjoy fast sympathetic peer review and rapid publication of accepted articles

Access all the published articles

Re-use any of the published material for personal use and teaching without further permission

\section{Customer Service}

If you have any further queries about your subscription, please contact our customer services team on +44 (0) 2071111105 or via email at support@bmj.com.

Visit casereports.bmj.com for more articles like this and to become a Fellow 